\title{
ПРОВІДНОМУ ЗАКЛАДУ ПІСЛЯДИПЛОМНОЇ ОСВІТИ НМАПО ІМЕНІ П. Л. ШУПИКА - 95 РОКІВ
}

Сьогодні Національна медична академія післядипломної освіти (НМАПО) імені П. Л. Шупика провідний в Україні заклад післядипломної освіти лікарів і провізорів, визнаний навчально-методичний та потужний науковий центр.

Історія цього закладу розпочалася у 1918 році, коли професійною Спілкою київських лікарів було створено Клінічний інститут для удосконалення лікарів. Передові представники медичної громадськості, серед яких М. А. Левитський, О. З. Лазарєв, С. Л. Скловський, Г. Б. Биховський, I. І. Фрумін та ін., вже тоді надавали важливе значення підвищенню кваліфікації лікарів. Мета закладу була чітко сформульована у його першому Статуті і передбачала спеціалізацію лікарів в галузі практичної і теоретичної медицини, набуття загального медичного стажу молодими лікарями, періодичну організацію повторювальних курсів для поповнення і оновлення знань лікарів та наукову роботу лікарів. Першим головою правління був професор М. А. Левитський. На початку свого існування клінічною базою інституту була лише одна поліклініка з обслуговування вдома та амбулаторія для хворих, згодом було відкрито аптеку та хімікобактеріологічну лабораторію.

Навчальний процес на початку існування закладу включав лише відвідування лекцій у вечірній час, вільний від практичної роботи лікаря. Систематичні заняття розпочалися лише у 1920 році, коли було зараховано на курси 117 лікарів. У кінці 20-х років у складі інституту було 9 основних кафедр, серед яких оториноларингології (1921, професор С. С. Ставракі), дерматовенерології (1921, професор О. Г. Лур'є), терапії (1921, професор О. Б. Бернштейн), хірургії (1922, професор Г. Б. Биховський), патологічної анатомії (1922, професор I. Т. Тітов), нервових хвороб (1923, професор Б. М. Маньковський), ортопедії і травматології (1926, професор І.Й. Фрумін), психіатрії (1927, канд. мед. наук I. О. Залкінд), урології (1929, профеcop А. А. Чайка).

В дані роки в управлінні закладом існувало двовладдя, оскільки навчально-наукову діяльність інституту фінансував Наркомосвіти, а лікувальну - Наркомздоров'я України. На початку 30 -х років відбулася корінна реорганізація вищої медичної школи України, відповідно до якої вища медична і фармацевтична освіта перейшли до відомства Наркомздоров'я України, що сприяло позитивним зрушен- ням у післядипломній освіті лікарів. Були визначені чіткі вимоги до базової підготовки лікарів та підвищення їх кваліфікації. Розвиток медицини, зростання потреб практичної охорони здоров'я, особливо у сільській місцевості, потребували подальшого удосконалення організації системи післядипломної освіти 3 розширенням спеціальностей. У довоєнні роки в інституті було створено ще 14 нових кафедр, всього ïx було 24, більшістю з яких керували відомі та досвідчені професори. Цей період ознаменувався також суттєвим внеском вчених інституту до скарбниці вітчизняної науки. Вчені інституту також були біля витоків створення нових типів медичних установ. Так, професор Є. Л. Скловський був одним із засновників дитячих лікувально-профілактичних установ м. Києва, громадського руху “Крапля молока", професор Г. Б. Биховський в 1932 р. організував при Київському рентгенологічному інституті онкологічний диспансер і першу в Києві онкологічну клініку (1934).

У цей період зародилася нова форма підвищення професійної освіти шляхом наближення системи післядипломної освіти безпосередньо до виробництва. На базах потужних на той час лікарняних установ Білої Церкви, Житомира, Коростеня, Черкас і Чернігова були створені філії окремих кафедр, пункти підвищення кваліфікаціїлікарів на чолі зі спеціально підготовленими в інституті спеціалістами. Розширення навчально-матеріальної бази та профільності спеціалізації і перепідготовки лікарів інститут, який щорічно готував понад тисячу фахівців, став одним 3 найпотужніших медичних навчально-наукових закладів країни довоєнного часу.

У роки Другої світової війни інститутприпинив свою діяльність, а його навчальна і матеріальна база були знищені під час тимчасової окупації Києва. Як і інші медики України, вчені інституту внесли свій вагомий внесок у здобутки медицини воєнного періоду, а окремі з них проявили себе талановитими організаторами військової медицини. В історію назавжди увійшли імена головного терапевта Північно-Кавказького та I Українського фронтів - завідувача кафедри терапії професора В. Х. Василенка, головного хірурга евакопункту I Українського фронту, генерал-майора медичної служби, завідувача кафедри урології професора А. А. Чайки та багатьох інших.

Вже через два тижні після звільнення Києва інститут відновив свою роботу. Основною базою інститу- 
ту став колишній 408-й Окружний військовий шпиталь та деякі лікувальні заклади міста.

У повоєнні роки основні зусилля були направлені на створення навчально-лікувальної бази інституту. У 1944 році навчальною базою інституту стала Київ ська обласна лікарня, де розмістилася більшість клінічних кафедр. Створювалися нові кафедри, розширювались спеціальності, що привело до суттєвого зростання числа підготовлених лікарів.

Реформування медичної галузі у 60-х роках було направлене на удосконалення та підвищення якості спеціалізованої медичної допомоги, що вимагало і суттєвих змін з боку медичної освіти та привело до подальшого розширення як кафедр, так і зростання кількості слухачів. У 1965 р. інститут переходить у підпорядкування Міністерства охорони здоров'я СРСР. До 1991 року в інституті проходили підвищення кваліфікації лікарі з різних куточків колишнього Радянського Союзу. У ці роки інститутом керували професор М. Н. Умовіст, який займав цю посаду протягом 25 років (1959-1984), а з 1984 р. - професор В. М. Гирін.

У роки незалежної України інститут зайняв пріоритетне положення в галузі післядипломної підготовки і перетворився в навчально-методичний центр МO3 України з цієї проблеми. Окремі кафедри (управління охороною здоров' я, медичної інформатики та обчислювальної техніки) були визначені МO3 як провідні з відповідних проблем. 31992 року були введені нові форми післядипломного навчання лікарів та провізорів, такі, як передатестаційні цикли, очно-заочне навчання лікарів-інтернів, цикли підготовки з ряду спеціальностей керівників та викладачів інститутів і факультетів удосконалення лікарів медичних вузів. Були розроблені і впроваджені в навчальний процес власні національні навчальні програми, атестаційні комп'ютерні системи для інститутів аналогічного профілю в державі.

13 травня 1996 року Постановою Кабінету Міністрів України в п'яту річницю незалежності нашої держави інститут набув статусу Київської медичної академії післядипломної освіти.

До 80-річчя академії, згідно з Постановою Кабінету Міністрів України № 513 від 20 квітня 1998 року “Про увічнення пам'яті П. Л. Шупика”, ій присвоєно ім'я видатного державного діяча і вченого - професора Платона Лукича Шупика (1907-1986), який двічі обіймав посаду міністра охорони здоров'я України (1952-1954, 1956-1969), вніс вагомий вклад у розвиток навчальної, наукової та матеріальної бази академії, протягом 14 років (1965-1979) завідував кафедрою соціальної медицини та організації охорони здоров'я (тепер - кафедра управління охороною здоров'я).

Указом Президента України В. А. Ющенка № 236 від 27 березня 2006 року Київській медичній академії післядипломної освіти імені П. Л. Шупика надано статус Національної.

32002 р. академію очолив відомий організатор охорони здоров'я, вчений, педагог, академік НАМН України, професор Ю. В. Вороненко, який зробив вагомий внесок у розвиток НМАПО імені П. Л. Шупика як провідного закладу післядипломної освіти, сучасного наукового та лікувального центру, у реорганізацію післядипломної освіти відповідно до міжнародних стандартів.

За останні двадцять років на базі академії створено ряд нових кафедр та підрозділів, які відповідають сучасним вимогам практичної охорони здоров'я та розміщені на клінічних базах європейського рівня. Національна медична академія післядипломної освіти імені П. Л. Шупика за роки існування стала найбільшим і провідним в Україні закладом післядипломної медичної освіти, потужним науковим центром, до складу якого входять 3 інститути, 5 факультетів, 80 кафедр, 5 центрів, 3 відділення. На сьогодні в штаті закладу більше 1600 співробітників, у тому числі понад 820 науково-педагогічних працівників, серед яких 226 докторів і 496 кандидатів наук.

Розроблені викладачами КМАПО ім. П. Л. Шупика типові навчальні плани і програми, комп'ютерні атестаційні програми використовуються усіма медичними установами та факультетами післядипломної освіти. Щорічно в академіі розробляється і оновлюється більше 100 навчальних планів і програм циклів тематичного удосконалення, видається більше 60 найменувань навчально-методичної літератури (підручники, навчальні та навчально-методичні посібники, довідники) для використання в навчальному процесі.

Щороку в академії проводиться близько 1,5 тис. циклів, навчається 2,5 тис. інтернів і 23 тис. лікарів і провізорів.

У свій ювілей академія може пишатися своєю матеріально-технічною базою, науковими здобутками та найціннішим скарбом - викладачами, велика частка яких є провідними спеціалістами у своїй галузі та знаними фахівцями не тільки у нашій країні, а й за кордоном. У різні часи тут працювали і працюють видатні вчені-академіки, члени-кореспонденти академій наук: М. М. Амосов, О. І. Арутюнов, Ф. Ю. Богданов, В. Д. Братусь, В. Х. Василенко, Ю. В. Вороненко 
(ректор академії з 2002 р.), О. С. Сфімов, Д. М. Калюжний, В. П. Комісаренко, Б. М. Маньковський, О. М. Марзєєв, Л. І. Медвідь, Л. В. Тимошенко, Д. Ф. Чеботарьов, М. Г. Шандала, О. О. Шалімов та інші.

На даний час в академії працюють: 2 Герої України, 1 академік НАН України та 6 академіків НАМН України, 3 академіки АН вищої школи України, 15 членів-кореспондентів НАМН України та 3 члени-кореспонденти НАН України, 33 заслужені діячі науки і техніки України, 32 лауреати Державної премії України в галузі науки і техніки, 66 заслужених лікарів України, 5 заслужених працівників освіти України, 3 заслужені раціоналізатори та винахідники України, 5 заслужених працівників охорони здоров'я України, 2 заслужені працівники фармації України, 1 заслужений юрист України. Засновниками нових в Україні наукових шкіл стали вчені академії М. М. Амосов, Ю. П. Вдовиченко, І. М. Ганжа, О. А. Свдощенко, С. В. Коханевич, С. Л. Мачерет, О. П. Мінцер, М. С. Поліщук, М. М. Сергієнко, Л. В. Тимошенко, А. І. Тріщинський, О. О. Шалімов.

Понад 30 провідних вчених - головні спеціалісти MO3 України, які працюють над удосконаленням якості медичної допомоги населенню.

Велике значення в академії завжди надавалось підготовці наукових кадрів. Сьогодні в академії функціонують 11 спеціалізованих рад по захисту докторських і кандидатських дисертацій з 13 спеціальностей. Наукові розробки вчених академії відомі не тільки в Україні і країнах СНД, але і в далекому зарубіжжі. Результати науково-дослідницьких робіт викладачів академії за останні двадцять років відображені в 448 монографіях, 112 підручниках, 565 навчальних посібниках, 170 довідниках, 876 методичних рекомендаціях та інформаційних листах, 633 патентах, доповідались на 298 наукових форумах. За останні 35 років вченими академії отримано більше 560 авторських свідоцтв на винаходи, окремі з яких запатентовані в США, Італії та інших країнах.

НМАПО імені П. Л. Шупика є засновником 25 професійних періодичних медичних видань.

Заклад успішно співпрацює із зарубіжними партнерами, зокрема: Словацьким медичним університетом; Люблінською медичною академією та університетом ім. Миколая Коперника (Польща); Ягелонським університетом; Сілезькою медичною академією; Іллінойським університетом (США); Санкт-Петербурзьким державним медичним університетом ім. М. І. Павлова та Університетом Оребро (Швеція); Міжнародною медичною академією ім. Швейцера (Польща); університетом м. Барі (Італія)-співпраця в рамках Міжуніверситетського центру досліджень і співпраці країн Східної, ПівденноСхідної Свропи (CIRCEOS); університетами штату Айова та Алабама (США); Білоруською медичною академією післядипломної освіти; Національним інститутом генетичної інженерії і біотехнології(Іран); Цюріхським університетом(Швейцарія); Міжнародною академією класичної гомеопатії (Греція) та іншими.

В клінічній ординатурі та аспірантурі на кафедрах академії щороку навчається більше 400 іноземців 3 54 країн світу, в тому числі США, Німеччини, Польщі, Лівану, Лівії, Сирії, Грузії, Азербайджану, Вірменії, Ірану, Греції, Індії, Китаю та інших країн.

Академія тісно співпрацює з закладами практичної охорони здоров’ я. Клінічна база складає майже 11 тис. ліжок у сучасних лікувальних закладах і науково-дослідних інститутах м. Києва. Співробітники щорічно надають консультативну допомогу близько 200 тис. хворим, виконують понад 20 тис. складних операцій.

Колектив академії на всіх етапах їі існування вносив і вносить вагомий внесок до скарбниці української медицини, сприяючи проведенню реформи системи охорони здоров'я і вищої медичної школи в Україні. 